\title{
Effect of combined oral contraceptive pills on some haemostatic parameters
}

\author{
Ahmed J. AL-Husaynee* Muna A. Kashmoola **
}

* Department of Obstetric and Gynecology, ${ }^{* *}$ Department of Pathology, College of Medicine, University of Mosul.

(Ann. Coll. Med. Mosul 2007; 33(1\&2):66-69)

Received:26 ${ }^{\text {th }}$ Feb 2007; Accepted:2 ${ }^{\text {nd }}$ Jan, 2008

\section{ABSTRACT:}

Objective: To assess our local status of markers of coagulation in response to combined oral contraceptive (COC) pill.

Methods: A prospective clinico- haematological study was carried out in private lab. Forty non smoker women on (COC) pill ( Levonorgestrel $0.25 \mathrm{mg}$ and ethinyl estradiol $0.05 \mathrm{mg}$ ) for 3 months and more; their ages ranging between thirty and thirty five with a control group of 40 women were studied during a period of 6 months starting from August 2006.

Most important haemostaic parameters including platelet count (PC) Prothrombin time (PT) and activated partial thromboplastin time (APTT), Fibrinogen and D-dimer were done for them.

Results: There was a significant increase in the mean values of $(P C)$, fibrinogen with $(P<0.05$, $<0.05)$ respectively, while the $P T$ and APTT were significantly reduced with $(P<0.05,<0.05)$ respectively. D-dimer was significantly positive in users than non users $(P<0.001)$.

Conclusion: there was some degree of pro-coagulant activity in women on COC and such females need monitoring of haemostatic parameters.

للتحري عن بعض معايير التجلط عند النساء اللاتي يستعملن حبوب منع الحمل المكون من مركبات الاستروجين،

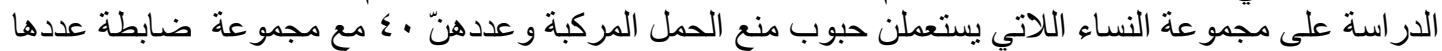

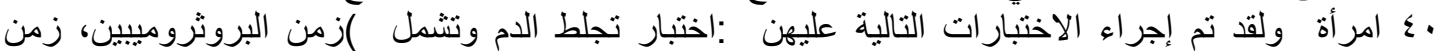

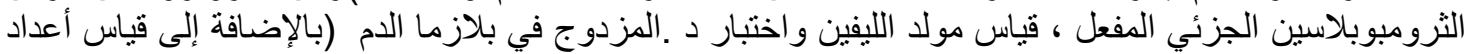
الصفيحات الدموية . الصنية

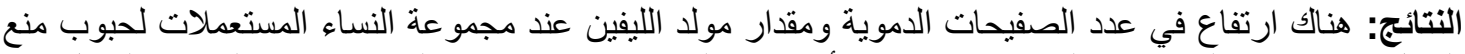

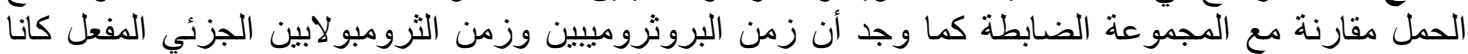

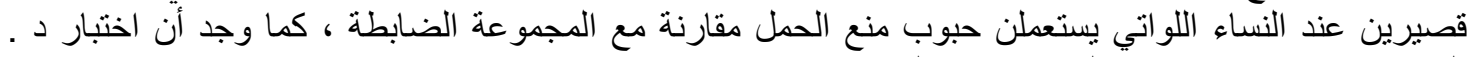

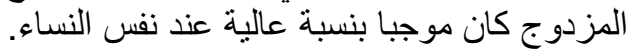

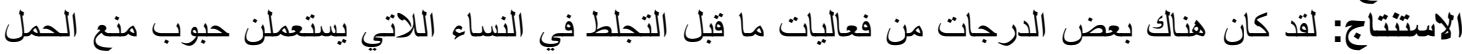

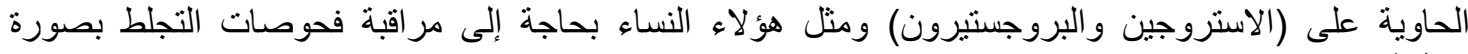


$t$ is estimated that more than 100 million women worldwide use the oral contraceptive pill $(\mathrm{OCP})^{(1)}$. Clinical and epidemiological studies indicate that use of OCP is associated with an increased risk of thrombotic disorders ${ }^{(2,3,4)}$. The pathogenesis underlying this apparent prothrombotic state is not clear. Increased coagulation is thought to be a primary factor in the increased thrombotic risk associated with oral contraceptive users than non users. Plasma concentration of several markers of coagulation have been shown higher in users compared with non-users of oral contraceptive $^{(5,6,7)}$. The present study assesses our local status of markers of coagulation in response to COC pills

\section{Subjects and Methods:}

The study was conducted prospectively in a private laboratory. Forty non-smoker women on COC pill (levonorgestrel $0.25 \mathrm{mg}$ and ethinylestradiol $0.05 \mathrm{mg}$ ) for no less than three months; their ages ranging between 30-35 years. The control group included forty women who were age matched and not on any type of oral contraceptive pills. The haemostatic parameters including ( platelet count, PT and APTT) were determined using standard haematological techniques described by Dacie and Lewis ${ }^{(8)}$.Plasma fibrinogen measurement was done by using Biomerieux/ Fibrinomat -68 452/ France Kit) that depends on clot based method of Clauss $^{(9)}$. Plasma D-dimer test was done by commercially available kit (Biomerieus/Ddimer Slidex direct -73-101/France kit). The same parameters were determined for the control group. Statistical analysis of data was done using chi-squared test and paired t-test

\section{Results:}

Table (1) shows the haemostatic parameters of the study population. The mean values of platelet count and fibrinogen were significantly higher in users than control $(\mathrm{P}<0.05, \mathrm{P}<0.05)$ respectively, while $\mathrm{PT}$ and APTT were reduced significantly $(P<0.05$, $\mathrm{P}<0.05)$ respectively in users than control. $D$-dimer was significantly positive in users than control X2 (1) $(p<0.001)$; table (2).

We found a significant negative correlation between PT and the duration of use of oral contraceptive with $(r=-0.8)$ figure (1). There was no significant correlation between platelet count and the duration of use of the oral contraceptive.

Table (1) shows the laboratory characteristics of the study population

\begin{tabular}{|c|c|c|c|c|c|}
\hline & \multicolumn{2}{|c|}{ Control $($ no. $=40)$} & \multicolumn{2}{|c|}{ "Patients" (no=40) } & \multirow[t]{2}{*}{$\mathrm{p}$-value } \\
\hline & Mean $\pm S D$ & Range & Mean \pm SD & Range & \\
\hline Platelet count $\times 10^{9} / \mathrm{L}$ & $210 \quad 50$ & $160-272$ & 340168 & $330-520$ & $<0.05$ \\
\hline $\mathrm{PT}(\mathrm{sec})$ & 12 & $11.5-13$ & 111.6 & $10-13$ & $<0.05$ \\
\hline APTT (sec) & 42 & $40-44$ & 353 & $32-38$ & $<0.05$ \\
\hline Plasma Fibrinogen $(\mathrm{g} / \mathrm{L})$ & 2. $8 \quad 0.6$ & $2.2-3.4$ & $3.2 \quad 2.6$ & 2- 6 & $<0.05$ \\
\hline
\end{tabular}


Table (2): D-dimer in women on ( COC) pills and the control

\begin{tabular}{|l|l|l|}
\hline & Negative (D-dimer) & Positive (D-dimer ) \\
\hline Women on COC & 5 & 35 \\
\hline Control & 32 & 8 \\
\hline
\end{tabular}

$\mathrm{X}^{2}(1):(P<0.001)$

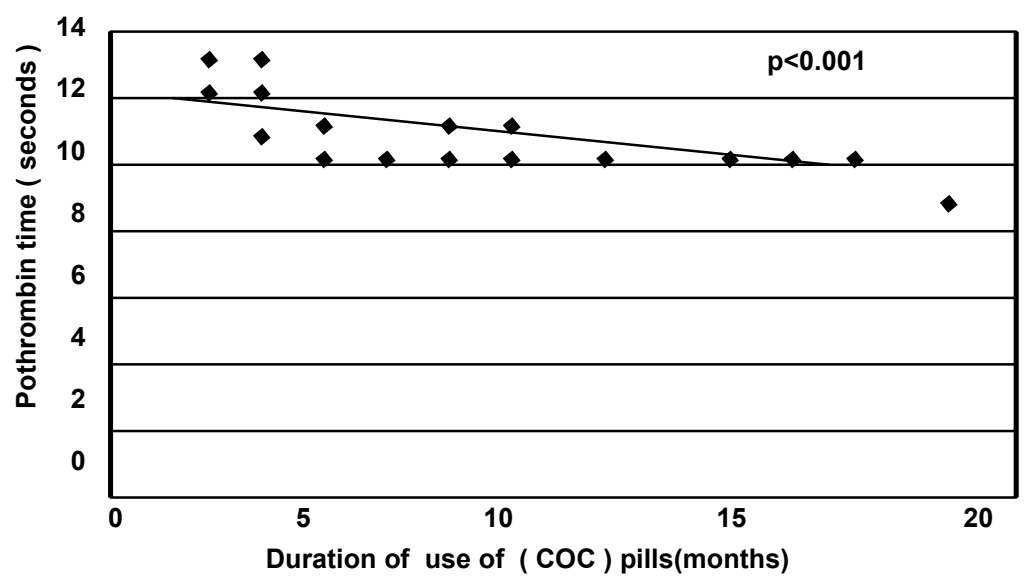

Figure (1) : Correlation between prothrombin time and the duration of use of ( $\operatorname{coc}$ ) pills.

\section{Discussion:}

The findings of the present study showed significant differences of most of the haemostatic parameters in users women than non-users. The platelet count in women on $\mathrm{COC}$ was significantly above the reference range value ${ }^{(9,10)}$. In our study the platelet count was significantly higher in users than non-users but still within the normal range.

High plasma fibrinogen level was significantly higher in women on COC for more than three months; this finding was noticed by Babatunde \& Olatunji but it was not agreed with Jose et al who mentioned there was no significant change in fibrinogen level or D-dimer during COC use ${ }^{(10-11) \text {. }}$

Significant positive D-dimer in users women was found in this study (table 2), the increase in D-dimer by $64 \%$ has also been observed during $\mathrm{COC}$ use due to fibrinolysis which is also activated in such women. ${ }^{(12,13)}$ In our study there was no other cause for positive D-dimer.

The reduction in PT and APTT were expected in such women because the plasma concentration of several markers of coagulation including Factors VII, VIII, X, have been shown to be higher compared with non users ${ }^{(5,6,7,14)}$

Jose et al mentioned a significant decrease in APTT while Babatunde and Olaun observed a significant reduction in PT but there was no significant reduction in APT.

We conclude that there is some degree of increase in pro-coagulant activity in women using $\mathrm{COC}$; such females need proper assessment and monitoring of haemostatic parameters. 


\section{References:}

1. World Health Organization. Cardiovascular disease, steroid hormone contraception: report of WHO scientific group. WHO Technical report series.1998; 877:1-89, 19 .

2. Jick, H, Jick SS, Gurewioch V, et al. Risk of venous thromoemblosim among users of third generation oral contraceptive with levonorgestrel before and after 1995: Cohort and Case control analysis. Br Med J.2000; 321:1190-1195

3. Tanis, BC, Van Den Bosch MAAJ, Kemmeren JM, et al. Oral contraceptives and the risk of myocardial infarction. N Engl J Med.2000; 345:1787-1793

4. Vandenbroucke, JP, Rosing J, Bloemenkamp KWM, et al. Oral contracptive and the risk of venous thrombosis. N Engl J Med.1994; 344:1527-1535.

5. Kluft $C$ and Lansink M. Effect of oral contraceptives on haemostasis variables. Thromb Haemost. 1997; 78:315-3262, 1997.

6. Mackie , J, Campbell S, G allimore M. et al Procoagulant changes induced by oral contraceptive are balanced by increased fibrinolytic tendency, Agents Action.1992;38:310-319.

7. Middeldorp, S. Meijers JCM, Van den Ende et al Effect on coagulation of levonorgestrel and desogestrel containing low dose oral contraceptive a cross-over Study thromb Haemost.2000; 84:4-8.

8. Dacie SJ, Lewis SM. Practical haematology $5^{\text {th }}$ ed. Edinburgh, London and New York, Churchill Livingstone, 2001:19.
9. Clauss A. Gerinnung Sphysiologieche schnelinethode zur bestimmung des fibrinogen. Acta Haematol 1957, 17:237. Cited by: Beutler E, Lichtman MA, Colle BS, Kipps TJ. William's Hematology $5^{\text {th }}$ ed. New York, McGraw Hill Company, 1995; 188.

10. Babatunde AS, Olantuji PO. Short term effect of oral contraceptive pills on some haemostatic parameters in healthy Nigerian women, Niger postgrad Med $\mathrm{J}$. 2004; 11(4):246-50.

11. Jose M, Luis C,Otavio C. et al . Effect of a combined oral contraceptive containing 20 microg ethinyl estradiol \& 75 microg gestoden on haemostatic parameters. Gynecol Endocrinal 2006;62:41

12. Quehenberger P, Kapiotis S, Partan C, et al. Studies on oral contraceptive induced changes in blood coagulation \& fibrinolysis \& the estrogen effect on endothelial cells, Ann Hematol.1993; 67:33-36.

13. Winkler $U$, Oberhoff $C$, Bier $U$, et al (Hemostatic effects of two oral contraceptive containing low doses of ethenylestradiol and either gestroden or norgestronat . Int Fert Menopausal study 1995;40:260-268

14. Greta L, Hoetzer, Brian L et al. Influence of oral contraceptive use endothelail tPA release in healthy premonopausal women. Am J Physiol Endocrinol Methal.2003; 284: E90-E95. 